\title{
Helminth parasites of Ctenosciaena gracilicirrhus (Perciformes: Sciaenidae) from the coast of Angra dos Reis, Rio de Janeiro State, Brazil
}

\section{Helmintos parásitos de Ctenosciaena gracilicirrhus (Perciformes: Sciaenidae) de la costa de Angra dos Reis, del estado de Rio de Janeiro, Brasil}

\author{
Melissa Q. Cárdenas ${ }^{1 凶}$, Berenice M. M. Fernandes ${ }^{1}$, Márcia C. N. Justo ${ }^{1}$, Antônia L. dos Santos ${ }^{2}$ and Simone \\ C. Cohen $^{1}$ \\ ${ }^{1}$ Laboratório de Helmintos Parasitos de Peixes, Instituto Oswaldo Cruz, Fiocruz, Av. Brasil 4365, 21045-900, Rio de Janeiro, RJ, Brazil. \\ ${ }^{2}$ Laboratório de Bioquímica de Proteínas e Peptídeos, Instituto Oswaldo Cruz, Fiocruz, Av. Brasil 4365, 21045-900, Rio de Janeiro, RJ, Brazil. \\ \melissaq@ioc.fiocruz.br
}

\begin{abstract}
During a survey of the helminth parasites of Ctenosciaena gracilicirrhus from the Atlantic Ocean, off Angra dos Reis, Rio de Janeiro State, Brazil, 10 species of metazoan parasites were collected: 1 species of Monogenea (Choricotyle rohdei); 3 species of Nematoda (Hysterothylacium sp. third stage larvae, Raphidascaris sp. third stage larvae, and Procamallanus (Spirocamallanus) pereirai third and fourth stages larvae and adults); 6 species of Digenea (Opecoeloides pedicathedrae, Opecoeloides melanopteri, Diplomonorchis leiostomi, Aponurus laguncula, Parahemiurus merus and Manteriella sp.). Choricotyle rohdei and Hysterothylacium sp. had the highest prevalence, mean intensity and abundance and an aggregated pattern of distribution was observed in both species. A positive correlation between the standard length of hosts and the parasitic abundance of Hysterothylacium sp. and C. rohdei was observed. The prevalence of $C$. rohdei was positively correlated with standard length of the host, while in Hysterothylacium sp. there was no correlation. Ctenosciaena gracilicirrhus represents a new host record to all species of Nematoda and Digenea presented herein. The genus Manteriella is reported for the first time in South America.
\end{abstract}

Key words: Digenea, Monogenea, Nematoda, fishes, South America.

Resumen. Durante un estudio de los helmintos de Ctenosciaena gracilicirrhus de la zona costera de Angra dos Reis, Rio de Janeiro, Brasil, 10 especies de parásitos metazoos fueron recolectados: 1 especie de Monogenea (Choricotyle rohdei); 6 de Digenea (Opecoeloides pedicathedrae, Opecoeloides melanopteri, Diplomonorchis leiostomi, Aponurus laguncula, Parahemiurus merus y Manteriella sp.); 3 nemátodos (Hysterothylacium sp. y Raphidascaris sp., ambas larvas de tercer estadio y Procamallanus (Spirocamallanus) pereira, larvas de tercer y cuarto estadios y adultos). Choricotyle rohdei y Hysterothylacium sp. presentaron la mayor prevalencia, intensidad media y abundancia, así como un patrón agregado de distribución. Se observó una correlación positiva entre la longitud estándar de los hospederos y la abundancia parasitaria de Hysterothylacium sp. y C. rohdei. La prevalencia de Choricotyle rohdei se relaciona positivamente con la longitud estándar del huésped, mientras que en Hysterothylacium sp., no hubo correlación. Ctenosciaena gracilicirrhus representa un nuevo registro de huésped para todas las especies de Digenea y Nematoda registrados en este trabajo. El género Manteriella se registra por primera vez en América del Sur.

Palabras clave: Digenea, Monogenea, Nematoda, peces, América del Sur.

\section{Introduction}

The study of helminth fauna of marine fishes is very important to understand biological and ecological aspects and the host-parasite relationship. Besides this, the status of a marine environment can be studied directly by using water quality parameters, or indirectly by using bioindicators such as fish parasites (Palm and Rückert, 2009).

Recibido: 27 mayo 2011; aceptado: 04 octubre 2011
Considering that most fish species are economically important, the presence of these helminths depreciates their commercial value, and some nematode, cestode and trematode larvae have a zoonotic potential.

Ctenosciaena gracilicirrhus (Metzelaar, 1919) inhabits coastal waters, usually over sandy mud bottoms, and is distributed in Nicaragua along the Caribbean coast and Atlantic coasts of South America to southern Brazil. It feeds mainly on shrimps (Froese and Pauly, 2011).

Recently, some studies have focused on characteristics of the community ecology of the metazoan parasites from the coastal zone of Angra dos Reis, State of Rio de Janeiro, 
Brazil (Tavares et al., 2004; Tavares and Luque, 2004a, b; Bicudo et al. 2005; Tavares and Luque, 2008). However, the helminth fauna of $C$. gracilicirrhus is being studied for the first time contributing to the knowledge of the biodiversity of the region.

\section{Materials and Methods}

From August 2007 to February 2009, 203 specimens of Ctenosciaena gracilicirrhus from the coast of Angra dos Reis, Rio de Janeiro State, Brazil (2300'24" S, $\left.44^{\circ} 19^{\prime} 05^{\prime \prime} \mathrm{W}\right)$ were collected in order to determine the helminth fauna of this host. For taxonomic studies the nematodes were rinsed in $0.7 \% \mathrm{NaCl}$ solution, fixed in hot AFA (2\% glacial acetic acid, 3\% formaldehyde, and $95 \%$ of $70 \%$ alcohol) and clarified in phenol $50 \%$. The gill archs were separated and the monogeneans collected were cold fixed in 5\% formaldehyde, with or without light cover glass pressure. The digeneans were cold fixed in AFA with slight compression under cover glass. Specimens of Monogenea and Digenea were stained with Langeron's alcoholic acid carmine, dehydrated in an ethyl-alcohol series, cleared in beechwood creosote and mounted in Canada balsam as permanent slides. Vouchers specimens were deposited in the "Coleção Helmintológica do Instituto Oswaldo Cruz" (CHIOC), Rio de Janeiro, Brazil. Calculations of the parameters of infection, related to prevalence, mean intensity, mean abundance were based on Bush et al. (1997). The quotient between variance and mean of parasite abundance (index of dispersion) was used to determine possible distribution patterns and was tested by the $d$ statistical index (Ludwig and Reynolds, 1988). Spearman's rank correlation coefficient ( $r s$ ) was used determine possible correlations between the standard length of hosts and parasites abundances of each species of parasite. To test correlations between the standard length and the prevalence of infection of each species of parasite, Pearsons's correlation coefficient $(r)$ was used, with angular processing of prevalence data (arc sine $\sqrt{ } x$ ) (Zar, 1996) and partition of host samples into twenty 0.7 $\mathrm{cm}$ length intervals. Statistical analyses were applied to parasite species with over $10 \%$ prevalence and the results considered significant when $p \geq 0.05$.

\section{Results}

Two hundred and three specimens of Ctenosciaena gracilicirrhus were analysed, with standard length that ranged from 3 to $17 \mathrm{~cm}(10 \pm 2.1 \mathrm{~cm})$. Ten species of helminth parasites were collected: 1 of Monogenea (Choricotyle rohdei Cohen, Cárdenas, Fernandes and Kohn, 2011); 6 of Digenea (Opecoeloides pedicathedrae Travassos, Freitas and Bührnheim, 1966, Opecoeloides melanopteri Amato, 1983, Diplomonorchis leiostomi Hopkins, 1941, Aponurus laguncula Looss, 1907, Parahemiurus merus (Linton, 1910) Manter, 1940 and Manteriella sp.), and 3 species of Nematoda (Hysterothylacium sp. third stage larvae, Raphidascaris sp. third stage larvae, and Procamallanus (Spirocamallanus) pereirai Annereaux, 1946 (third stage larvae, fourth stage larvae and adults).

Choricotyle rohdei and Hysterothylacium sp. had the highest prevalence, mean intensity and abundance (Table 1). Although Digenea was the group that showed a high diversity of species, they presented a low prevalence and mean intensity (Table 1).

C. rohdei and Hysterothylacium sp. showed a typical aggregated distribution pattern presenting an index of dispersion $(\mathrm{DI}=12.6, d=52.2$ and $\mathrm{DI}=30.8, d=92.4)$, respectively.

Spearman's rank correlation coefficient indicated a positive correlation between the standard length of hosts and the parasitic abundance of Hysterothylacium sp. and C. rohdei. Pearsons's correlation coefficient showed that the prevalence of $C$. rohdei was positively correlated with standard length of the host, while in Hysterothylacium sp. there was no correlation (Table 2).

The host sex does not influence the prevalence and abundance of infection, (Choricotyle $\mathrm{Z}_{\mathrm{c}}=-0.18, \mathrm{P}=0.78$ and Hysterothylacium $\mathrm{Z}_{\mathrm{c}}=-0.11, \mathrm{P}=0.99$ ).

\section{Discussion}

Previous studies on helminth parasites from $C$. gracilicirrhus were published by Pereira and Boeger (2005) with a proposition of a new species of trypanorhynch, Heteronybelinia annakohnae, collected from Rio Grande and also reported Progillotia dollfusi Carvajal and Rego, 1983 from Rio de Janeiro, both in Brazil. Recently, a new monogenean species, Choricotyle rohdei was described from this host (Cohen et al., 2011). In the present paper, C. gracilicirrhus is referred to as a new host for all species of Nematoda and Digenea, and the detection of the genus Manteriella Yamaguti, 1958 represents the first report of the genus in South America.

The presence of distinct larval helminths suggests the possibility that $C$. gracilicirrhus occupies an intermediate level in the marine food web. Nematodes of the Ascaridoidea (families Anisakidae and Raphidascarididae) naturally parasitize fishes, cephalopods, marine mammals and piscivorous birds, and humans can also become accidental hosts by ingestion of infected fish. The presence of anisakid larvae on the viscera and flesh may have an impact upon visual aesthetics and the market value, and parasite removal only adds to the product cost whilst 
Table 1. Prevalence (P), mean intensity (MI), mean abundance (MA) and site of infection of the parasites from Ctenosciaena gracilicirrhus from the coastal zone of Angra dos Reis, Rio de Janeiro State, Brazil

\begin{tabular}{|c|c|c|c|c|c|}
\hline Parasites & $P \%$ & $I R$ & $I / M I(S D)$ & $M A(S D)$ & Site of Infection \\
\hline \multicolumn{6}{|l|}{ MONOGENEA } \\
\hline Choricotyle rohdei (CHIOC 37.473-37.491) & 25.1 & $1-19$ & $1.96 \pm 2.56$ & $0.49 \pm 1.55$ & Gills \\
\hline \multicolumn{6}{|l|}{ DIGENEA } \\
\hline Aponurus laguncula (CHIOC 37.535) & 0.50 & - & $2 *$ & - & Intestine \\
\hline Diplomonorchis leiostomi (CHIOC 37.534) & 0.50 & - & $1 *$ & - & Intestine \\
\hline Manteriella sp. (CHIOC 37.539) & 0.50 & - & $1 *$ & - & Intestine \\
\hline Opecoeloides melanopteri (CHIOC 37.537 ) & 2.50 & - & 1.00 & $0.02 \pm 0.15$ & $\begin{array}{l}\text { Stomach } \\
\text { Intestine }\end{array}$ \\
\hline Opecoeloides pedicathedrae (CHIOC 37.536) & 7.40 & $1-2$ & $1.13 \pm 0.35$ & $0.08 \pm 0.31$ & Intestine \\
\hline \multirow{2}{*}{\multicolumn{6}{|c|}{$\begin{array}{l}\text { Immature specimen (CHIOC 37.538) } \\
\text { NEMATODA }\end{array}$}} \\
\hline & & & & & \\
\hline Hysterothylacium sp. (larvae) (CHIOC 35.772) & 10.30 & $1-12$ & $1.81 \pm 2.4$ & $0.19 \pm 0.9$ & Body Cavity Stomach \\
\hline $\begin{array}{l}\text { Procamallanus }(S .) \text { pereirai (adults and larvae) } \\
\text { (CHIOC } 35.773,35.775,35.776)\end{array}$ & 7.40 & $1-2$ & $1.07 \pm 0.22$ & $0.08 \pm 0.30$ & Intestine \\
\hline $\begin{array}{l}\text { Raphidascaris sp. (larva) } \\
\text { (CHIOC 35.774) }\end{array}$ & 0.50 & - & $1 *$ & - & Intestine \\
\hline
\end{tabular}

$(\mathrm{SD})=$ Standard deviation, ${ }^{*}$ only one specimen parasitized.

Table 2. Values of Spearman's rank correlation coefficient $(r s)$ and Pearson's correlation coefficient $(r)$ obtained in relations between standard length of host, abundance and prevalence of Choricotyle rohdei and Hysterothylacium sp.

\begin{tabular}{lcccc}
\hline Parasite species & $r s$ & $p$ & $r$ & $p$ \\
\hline Choricotyle rohdei & $0.754^{*}$ & $<0.0001$ & $0.599^{*}$ & 0.0052 \\
Hysterothylacium sp. & $0.535^{*}$ & $<0.0001$ & 0.416 & 0.0679 \\
\hline
\end{tabular}

$p=$ level of significance, $(*)$ significant values.

further reducing its attraction to consumers (Doupé et al. 2003).

The present work provides a new host record for third stage larvae of Hysterothylacium sp. and Raphidascaris sp. Only a single individual of Raphidascaris sp. was found in the intestine, which may indicate that C. gracilicirrhus is an accidental host for this species. However, Hysterothylacium sp. had a high prevalence indicating that C. gracilicirrhus is an important host for this alogenous endohelminth species.

Camallanids are considered a health problem for fishes when maintained in a closed ecosystem in the presence of suitable intermediate hosts (Rychlinski and Deardorff, 1982). Most species of Procamallanus (Spirocamallanus) are parasites of freshwater and marine hosts in South America. The larval stages of $P$. $(S$.) pereirai have been reported in 3 marine fish species of the family Sciaenidae: Nebris microps Cuvier, 1830, Paralonchurus brasiliensis (Steindachner, 1875), Macrodon ancylodon (Bloch and Schneider, 1801) and Stellifer brasiliensis (Schulz, 1945), and 1 more of the family Cyanoglossidae: Symphurus tesselatus (Quoy and Gaimard, 1824), from Rio de Janeiro State (Santos et al., 1999).

Choricotyle rohdei and Hysterothylacium sp. showed the typical aggregated pattern of distribution observed in many parasite systems. According to Holmes (1990), the aggregated distribution may increase the reproductive efficiency in some adult species, since it enhances mating opportunities. Besides, this distribution pattern improves the opportunity to infect the host (Dobson, 1990).

The high abundance of $C$. rohdei might be related to the population density increase of $C$. gracilicirrhus in offshore reproductive grounds, which might facilitate transmission of ectoparasites with a direct life cycle, similar to that suggested by Venerus et al. (2005) in Pseudopercis semifasciata off Patagonia.

A positive correlation between the standard length of hosts and the parasitic abundance of $C$. rohdei and Hysterothylacium sp. indicates that the number of specimens of parasites is greater as the standard length of fishes increases. The same occurs between the standard length of host and the prevalence of $C$. rohdei. In Hysterothylacium sp., however, no correlation was observed between the prevalence of parasites and the standard length of the host.

In our results we observed that host sex does not influence the prevalence and abundance of infection. According to Luque et al. (1996) and Alves et al. (2002) the absence of correlations in parasite prevalence and abundance with the sex of the host fish is a widely documented pattern, and interpreted as a consequence of absence of sexual differences in some biological aspects of the fish. 
As mentioned by Polyanski (1961), quantitative and qualitative changes in parasitism are expected as the fish grows. Saad-Fares and Combes (1992) related that ontogenetical changes in the feeding behavior might have an influence on parasite prevalence and abundance in the host size classes. However, this pattern cannot be generalized because in many host-parasite species systems the correlation is positive but weak and non-significant (Saad-Fares and Combes, 1992; Poulin, 2000).

The present study increases the data on the biodiversity and enhances the knowledge of the helminthes with regard to public health importance, such as the nematodes of family Anisakidae. However, more information about host biology is needed to improve the interpretation of these parasitological patterns, in an ecological framework incorporating pertinent environmental and biological information, as recommended by Marcogliese (2001).

\section{Acknowledgments}

The authors are grateful to Dr Pedro José Diniz de Figueiredo from "Central Nuclear Almirante Álvaro Alberto, Eletrobrás, Eletronuclear, Angra dos Reis" and Dr Aderval Ferrari Vaz de Almeida from "Laboratório de Monitoração Ambiental, Eletronuclear, Angra dos Reis", for the facilities and infrastructure offered to examine the fishes, and by the classification of the hosts.

\section{Literature cited}

Alves, D. R., J. L. Luque and A. R. Paraguassú. 2002. Community ecology of the metazoan parasites of Pink Cuskeel, Genypterus brasiliensis (Ostechthyes: Ophidiidae) from the coastal zone of the State of Rio de Janeiro, Brazil. Memórias do Instituto Oswaldo Cruz 97:683-689.

Bicudo, J. A., L. E. R.Tavares and J. L. Luque. 2005. Larvas de Anisakidae (Nematoda: Ascaridoidea) parasitas da cabrinha Prionotus punctatus (Bloch, 1793) (Osteichthyes: Triglidae) do litoral do Estado do Rio de Janeiro, Brasil. Revista Brasileira de Parasitologia Veterinária 14:109-118.

Bush, A. O., K. D. Lafferty, J. M. Lotz and A. W. Shostak. 1997. Parasitology meets ecology on its own terms: Margolis et al. revisited. Journal of Parasitology 83:575-83.

Cohen, S. C., M. Q. Cárdenas, B. M. M. Fernandes and A. Kohn. 2011. On a new species of Choricotyle (Monogenea, Diclidophoridae) a parasite of a marine fish from the littoral of the State of Rio de Janeiro, Brazil. Comparative Parasitology 78:261-264.

Dobson, A. P. 1990. Models of multi-species parasites-host communities. In Parasite communities: patterns and process, G. W. Esch, A. O. Bush and J. Aho (eds.). Chapman and Hall, New York. p. 261-287.
Doupé, R. G., A. J. Lymbery, S. Wong and R. P. Hobbs. 2003. Larval anisakid infections of some tropical fish species from north-west Australia. Journal of Helminthology 77:363-365.

Froese, R. and D. Pauly (Eds.) 2011. FishBase. World Wide Web electronic publication. www.fishbase.org; last access: 01.II.2011.

Holmes, J. C. 1990. Competition, contacts, and other factors restricting niches of parasitic helminths. Annales de Parasitologie Humaine et Comparée 65:69-72.

Ludwig, J. A. and J. F. Reynolds. 1988. Statistical Ecology: A primer methods and computing. Wiley-Interscience Publications, New York. 337 p.

Luque, J. L., J. F. R. Amato and R. M. Takemoto. 1996. Comparative analysis of the communities of metazoan parasites of Orthopristis ruber and Haemulon steindachneri (Osteichthyes: Haemulidae) from the southeastern Brazilian littoral: I. Structure and influence of the size and sex of hosts. Revista Brasileira de Biologia 56:279-292.

Marcogliese, D. J. 2001. Pursuing parasites up the food chain: implications of food web structure and function on parasite communities in aquatic systems. Acta Parasitologica 46:82-93.

Palm, H. W. and S. Rückert. 2009. A new approach to visualize ecosystem health by using parasites. Parasitology Research 105:539-53.

Pereira, J. Jr. and W. A. Boeger. 2005. Larval tapeworms (Platyhelminthes, Cestoda) from sciaenid fishes of the southern coast of Brazil. Zoosystema 27:5-25.

Polyanski, Y. I. 1961. Ecology of parasites of marine fishes. In Parasitology of Fishes, V. A. Dogiel, G. K. Petrushevski and Y. I. Polyanski. Oliver and Boyd (eds.). Oliver \& Boyd. Edinburgh and London. p. 47.

Poulin, R. 2000. Variation in the intraspecific relationship between fish length and intensity of parasitic infection: biological and statistical causes. Journal of Fish Biology 56:123-137.

Rychlinski, R. A. and T. L. Deardorff. 1982. Disease prevention and control. Spirocamallanus: a potential fish health problem. Freshwater and Marine Aquarium 5:79-83.

Saad-Fares, A. and C. Combes. 1992. Abundance/host size relationships in a fish trematode community. Journal of Helminthology 66:187-192.

Santos, C. P., M. Q. Cárdenas and H. Lent. 1999. Studies on Procamallanus (Spirocamallanus) pereirai Annereaux, 1946 (Nematoda: Camallanidae), with new host records and new morphological data on the larval stages. Memórias do Instituto Oswaldo Cruz 94:635-40.

Tavares, L. E. R., A. J. A. Bicudo and J. L. Luque. 2004. Metazoan parasites of needlefish Tylosurus acus (Lacépède, 1803) (Osteichthyes: Belonidae) from the coastal zone of the State of Rio de Janeiro, Brazil. Revista Brasileira de Parasitologia Veterinária 13:36-40. 
Tavares, L. E. and J. L. Luque. 2004a. Community ecology of metazoan parasites of the later juvenile common snook Centropomus undecimalis (Osteichthyes: Centropomidae) from the coastal zone of the state of Rio de Janeiro, Brazil. Brazilian Journal Biology 64:523-529.

Tavares, L. E. and J. L. Luque. 2004b. Community ecology of the metazoan parasites of white sea catfish, Netuma barba (Osteichthyes: Ariidae), from the coastal zone of the state of Rio de Janeiro, Brazil. Brazilian Journal of Biology 64:169-76.
Tavares, L. E. R. and J. L. Luque. 2008. Similarity between metazoan parasite communities of two sympatric brackish fish species from Brazil. Journal of Parasitology 94:985989.

Venerus, L. A., L. Machinandiarena, M. D. Ehrlich and A. M. Parma. 2005. Early life history of the Argentine sandperch Pseudopercis semifasciata (Pinguipedidae) off northern Patagonia. Fishery Bulletin 103:195-206.

Zar, J. H. 1996. Biostatistical analysis. 3rd ed., Prentice-Hall Inc., New Jersey, Upper Saddle River. 662 p. 